Araştırma / Research

\title{
GERİ DÖNÜŞÜM SEKTÖRÜNDE CEVHER HAZIRLAMA TEKNOLOJILERININ KULLANIMI
}

\author{
Serkan ÇAYIRLI (ORCID: 0000-0003-3348-6601) ${ }^{{ }^{*}}$ \\ Öner Yusuf TORAMAN (ORCID: 0000-0003-3585-7023) ${ }^{1}$ \\ ${ }^{1}$ Maden Mühendisliği Bölümü, Mühendislik Fakültesi, Niğde Ömer Halisdemir Üniversitesi, Niğde, Türkiye
}

Geliş / Received: 16.11.2018

Kabul / Accepted: 24.12.2018

\begin{abstract}
ÖZ
Önemi giderek artan katı atıklar (plastik, cam, kâğıt, elektronik vb.) içerdiği değerli kısımlar bakımından yeni ve ikincil bir hammadde kaynağı ve çevre konusu olarak kabul edilmektedir. Cevher hazırlama teknolojileri söz konusu katı atıkların geri dönüşümü konusunda geniş bir uygulama alanı sağlamaktadır.

Cevher hazırlama işlemleri, bir cevherdeki çeşitli mineralleri, endüstrinin gereksinimine en uygun hammadde haline getirmek ve ekonomik değer taşıyanları taşımayanlardan ayırmak için yapılan işlemlerin tümü ile ifade edilir. Bu süreç, cevherin yer kabuğundan üretilmesinden itibaren başlayıp, endüstrinin istediği özellikleri taşıyan bir hammaddenin hazırlanmasına veya düşük tenörlü bir cevherin, metal üretimi için uygun bir madde haline getirilmesine kadar devam etmektedir. Hem cevher hazırlama da hem de geri dönüşüm endüstrisinde kullanılan proses ve ekipmanlar bakımından teknolojik birçok benzerlik olup esas amaç değerli malzemelerin değersizlerden ayırımıdır. Geri dönüşüm endüstrisinde kullanılan yöntemlerin çoğunun cevher hazırlama teknolojisinden geliştirildiği söylenebilir.

$\mathrm{Bu}$ çalışma ile geri dönüşüm endüstrisinde kullanılan cevher hazırlama ekipmanları ve prosesleri hakkında güncel bilgiler verilmiş ve ayrıca uygulama örnekleri sunulmuştur.
\end{abstract}

Anahtar kelimeler: Cevher hazırlama, geri dönüşüm, katı atık, zenginleştirme.

\section{USAGE OF MINERAL PROCESSING TECHNOLOGIES IN THE RECYCLING INDUSTRY}

\begin{abstract}
Solid wastes which increase in importance (plastic, glass, paper, electronics, etc.) are regarded as new and secondary raw material resources and environment in terms of valuable parts. Mineral processing technologies provide a wide range of applications for the recovery of solid waste.

Mineral processing is expressed as all the processes done to make the various minerals in an ore the most suitable raw material for the needs of the industry and to distinguish them from those who do not carry economic value. This process starts with the production of the ore from the earth's crust, until the preparation of raw material with the characteristics that the industry wants, or a low-grade ore, to be made into a suitable substance for the production of metal continues. There are many technological similarities in terms of the processes and equipment used in both the mineral processing and recycling industries, and the main purpose is to separate valuable materials from worthless ones. It can be said that most of the methods used in the recycling industry have been developed from mineral processing technology.

In this study, current information about the mineral processing equipments and processes used in the recycling industry has been given and also the application examples are presented.
\end{abstract}

Keywords: Mineral processing, recycling, solid waste, beneficiation

${ }^{*}$ Corresponding author / Sorumlu yazar. Tel.: +90 3882252350 ; e-mail / e-posta: scayirli@ohu.edu.tr 


\section{GİRIŞ}

Gelişen teknoloji yüksek yaşam standartları sağlarken tüketimi arttırmakta, artan tüketim ihtiyacının karşılanması için ise daha çok üretim yapılmaktadır. Yapılan üretim ile birlikte uzun vadede ülkemizde ve dünyada katı atıkların miktarı artmaya başlamış depo alanları yetersiz hala gelmiştir. Bununla birlikte çevre sorunlarının artması, doğal kaynakların israfı, enerji kullanımının fazlalaşması ülke ve üreticileri çeşitli arayışlara itmiştir. Süreç içerisinde geri dönüşüm yöntemleri geliştirilerek depo alanlarında büyük miktarlarda biriken katı atıklar yeni/ikincil bir hammadde kaynağı olarak düşünülmüştür.

Katı atıkların menşeine göre sınıflandırılarak içindeki değerli bileşenlerin fiziksel, kimyasal, fiziko-kimyasal ve biokimyasal yöntemlerin birinin veya birkaçının kullanılmasıyla tekrar kullanılabilir ürünlere veya enerjiye dönüştürülmesi; doğal kaynak israfını ve atık miktarını azaltırken, ekonomiye ve çevre bilincine katkı sağlamaktadır. Örneğin kullanılmış kâğıdın tekrar kullanılması hava kirliliğini \%74-94, su kirliliğini \%35, su kullanımını \%45 azaldığı ve bir ton atık kâğıdın kâğıt hamuruna katılmasıyla 8 ağacın kesilmesi önlenebilmektedir. Plastik ambalaj atıklarının geri kazanılması sonucu ise petrolden tasarruf edilmektedir. Dönüşen her ton cam için, 100 litre petrol tasarrufu sağlanabilmektedir. Ayrıca, elektronik atıklardan geri dönüşüm ile metal ve malzemelerin elde edilmesi, cevherlerden elde edilmesi süreçlerine göre daha az enerji (\%60-95) sarfiyatiyla yapılabilmektedir [1].

Cevher hazırlama yöntemleri atık geri dönüşümünde geniş bir uygulama alanına sahiptir. Sadece önemli temel işlemler değil, aynı zamanda cevher hazırlamada kullanılan zenginleştirme tekniklerinin birçoğu geri dönüşüm endüstrisinde uygulama alanı bulmuştur [2]. Katı atık geri dönüşümünde, cevher zenginleştirme süreçlerinde olduğu gibi, atığı oluşturan malzemeler arasında fiziksel, fiziko-kimyasal ve kimyasal özellik farkları aranmaktadır. Bu ayrımdan yola çıkılarak atıkların birbirinden ayrılması gerçekleştirilmektir. Atıklar arasındaki fiziksel özellik farkları en çok yararlanılan özellik olup, cevher zenginleştirme işlemlerinde genelde yararlanılan yoğunluk ve manyetik duyarlılık gibi özelliklerdir [3]. Bunun yanı sıra atıkların fiziko-kimyasal ve kimyasal özellikleri de zenginleştirme işlemlerinde aktif olarak kullanılmaktadır.

$\mathrm{Bu}$ çalışma da geri dönüşüm endüstrisinde kullanılan cevher hazırlama ekipmanları ve prosesleri hakkında güncel bilgiler verilmiş ve ayrıca uygulama örnekleri sunulmuştur.

\section{ATIKLARIN GERİ DÖNÜȘÜMÜNDE UYGULANAN CEVHER HAZIRLAMA YÖNTEMLERI}

Katı atıklar menşeine göre kaynağında sınıflandırıldıktan sonra türlerine göre uygulama tesislerinde ayırma süreçleri başlamaktadır. Aşağıda bu ayırma yöntemleri kısaca tanıtılacaktır.

\subsection{El ile Ayıklama ve Otomatik Ayırma}

Karışık olarak geri dönüştürülebilir malzemelerin ayrıştırılması elle veya otomatik sistemlerle yapılmaktadır (Şekil 1). El ile ayıklama sistemi işçiler tarafından gerçekleştirilirken daha iri parçalar için uygulanmaktadır. Otomatik ayrıştırmada ise geri dönüştürülecek malzemenin özelliğine göre farklı sensörler (optik, NIR- Near Infrared, X-ışını dedektörleri ve metal sensörleri) ile çalışan ayırıcılar kullanılabilmektedir [4]. Bu sistemde makinanın özelliğine göre daha da küçük parçalar sisteme beslenebilmektedir (kırma ve eleme işlemlerinden sonra). Plastik geri dönüşümünde otomatik ayırıcılar şeffaf, açık mavi, koyu mavi, yeşil ve diğer renkli PET şişelerin birbirinden ayrıştırılması için kullanılmaktadır. Plastiklerin dışında atık pillerin sınıflandırılmasında da el ile ayırma ve optik ayırma başarıyla uygulanmaktadır [5].
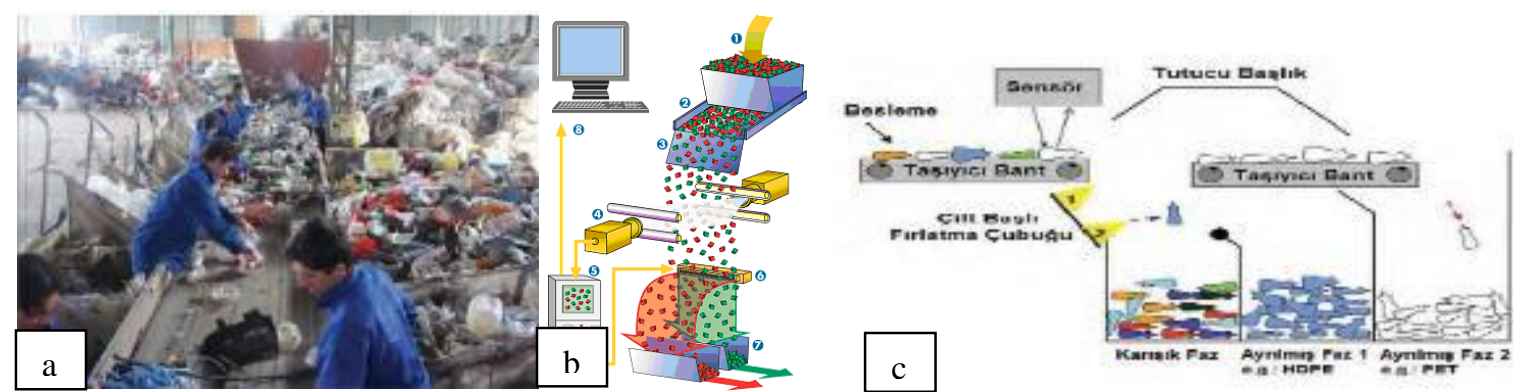

Şekil 1. Atıkların türüne göre ayrıştırılması (a), optik ayırıcı şematik görüntüsü (b) ve PET şişe ayırıcı $[4,6]$ 


\subsection{Manyetik Ayırma}

Farklı manyetik duyarlılığa sahip atıkların uygun bir manyetik alan içinde, başlıca manyetik kuvvet olmak üzere, çeşitli kuvvetlerin (yerçekimi, sürtünme, merkezkaç, vs.) birleşik etkilerine dayanılarak, birbirinden ayrılması yoluyla gerçekleştirilen ayırma yöntemidir. Geri dönüşüm sisteminde demir içeren bileşenlerin demir içermeyenlerden ayrılmasında yaygın olarak kullanılmaktadır. Birçok tipte manyetik ayırıcı olup bunlardan tamburlu olanlar en çok kullanılan tipleridir (Şekil 2).

Eddy Akımlı ayırıcılar ise sert veya yarı-sert alüminyum ambalaj atıklarının (meşrubat kutusu, kaplar vb.) geri kazanılmasında kullanılmaktadır. Tüm evsel atıklar arasında bulunabilecek alüminyum "Eddy Akım (Eddy Current)" metodu ile diğer atıklardan ayrılmaktadır. Eddy Akımlı ayırıcının (Şekil 3) oluşturduğu elektromanyetik alandan atık malzemeler geçerken, alüminyum ve demir içermeyen metal malzemeler bir hareket kazanarak dışarı doğru itilirler ve böylece diğer malzemelerden ayrılmış olurlar [7, 8].
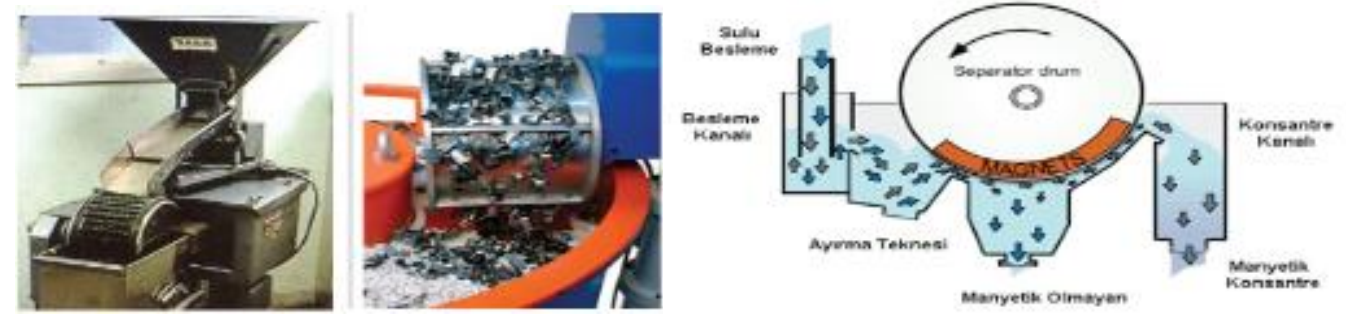

Şekil 2. Tambur tipi kuru ve yaş manyetik ayırıcı görüntüsü $[8,9]$

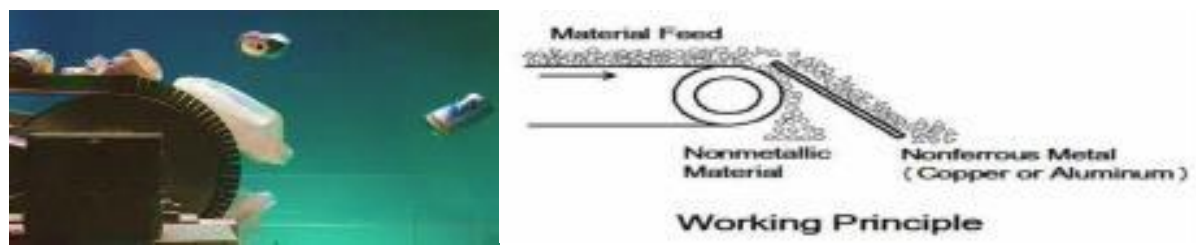

Şekil 3. Eddy akımlı manyetik seperatör ve çalışma prensibi $[10,11]$

\subsection{Elektrostatik Ayırma}

Bir elektrikli alan içinde (yüksek voltajl1), atıkların iletken bir yüzey arasındaki iletkenlik farkından yararlanarak yapılan ayırmaya elektro - statik ayırma denir. Bu yöntemde, elektrik alan kuvvetleri ve taneye etki eden gravite, santrifüj kuvveti gibi diğer kuvvetler ayarlanarak farklı ayrımlar yapılabilir [2]. Şekil 4' de bir tambur tipi bir elektro statik ayırıcının çalışma prensibi gösterilmektedir. Elektro statik ayırma yöntemiyle, bakır telleri izolasyon malzemelerinden, termoplastiği kauçuktan ve pet şişelerin geri dönüşümü gerçekleştirilmektedir.
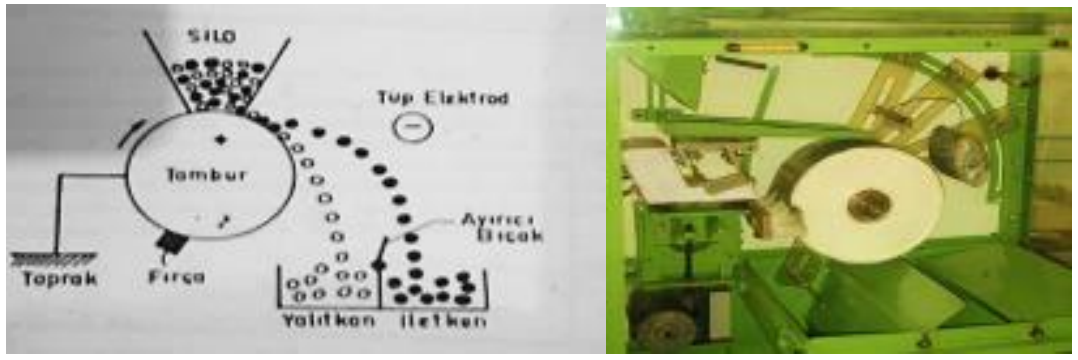

Şekil 4. Elektro statik ayırıcı çalışma prensibi $[12,13]$

Gelişen teknolojiyle birlikte Triboelektrik ayırıcılar geri dönüşüm sitemlerinde kullanılmaya başlanmıştır. Bu sistem diğer elektrostatik ayırıcılara göre daha ince boyutta malzemelerin yüksek verimle ayrılmasına olanak sağlamaktadır (Şekil 5). Triboelektrik ayırma sistemi karışık kâğıt atıklarının ayırımında, fotoğraf filmlerinin kağıttan ayrılmasında, PVC (Poli Vinil Klorid) kauçuk ayırımında, ABS (Akrilonitril Bütadien Stiren) ve PMMA (Polimetil Metakrilat) ayırımda kullanılmaktadır. Ayrıca yapılan akademik araştırmalarda triboelektrik ayırma yöntemi kullanılarak PVC, PET (Polietilen Tereftalat), ve PE (Polietilen), karışımından PVC \%99 
oranıyla kazanılmıştır [14]. Başka bir çalışmada ise devre kartlarının metalik olmayan kısımlarından inorganik maddelerin uzaklaştırılmasında başarıyla uygulanmıştır [15].
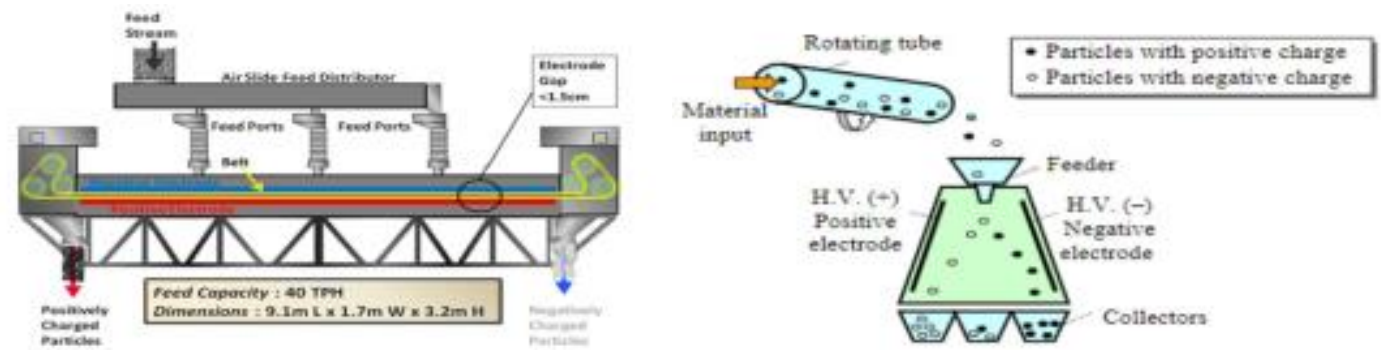

Şekil 5. Bant tipi ve serbest düşüş triboelektrik ayırıcı $[16,13]$

\subsection{Gravite Yöntemleri ile Ayırma}

Atık malzemelerin aralarındaki özgül ağılık farklılığının neden olduğu, akışkan ortamlardaki hareket farklılığına dayanılarak, birbirlerinden ayrılması ile gerçekleştirilen ayırma olarak tanımlanabilir. Özgül ağırlık farkı ile ayırmada akışkan ortam olarak çoğunlukla su, bazen sudan daha ağır bir akışkan, zaman zamanda hava kullanılır. Jigler, hidrosiklonlar, çöktürme tankları, sallantılı masalar, havalı ayırıcılar (tarımda kullanılan) ve ağır ortam ayırıcıları ayırım için kullanılan gravite cihazları olarak sıralanabilir (Şekil 6). Bu cihazlar geri dönüşüm tesislerinde demir ve demirden ağır olan malzemelerin, kâğıt, plastik, cam gibi hafif kısımlarından ayrılmasinda kullanılmaktadır.
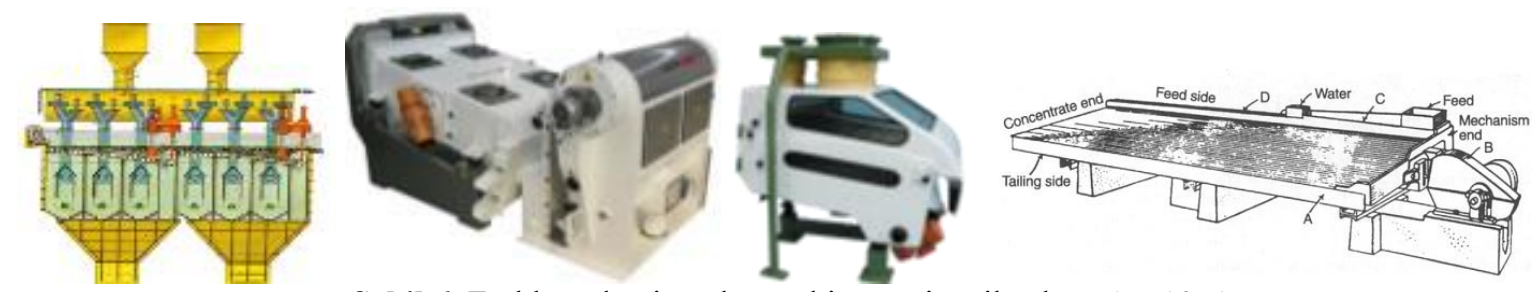

Şekil 6. Farklı mekanizmalara sahip gravite cihazları $[17,18,19]$

\subsection{Flotasyon Yöntemi}

Flotasyonun alışılagelmiş işlevi, cevher zenginleştirme alanında kıymetli mineralin kıymetsizden ayrılması olarak bilinir. $\mathrm{Bu}$ ayırım minerallerin suyla ıslanıp ıslanamamazlık farkına göre yapılmaktadır. Yani kıymetli mineral su ile ıslanıyor ise kıymetsiz mineral sslanmaz olmalı veya bunun tersi geçerli olmalıdır. Bu fark, çoğunlukla reaktifler yardımı ile yapay olarak yaratılabilmektedir. Bu sayede de flotasyonun kullanım alanı çok genişlemiştir [20]. Flotasyon; madencilik sektörü dışında atık kâğıt, atık su, atık jips ve atık plastiklerin (Şekil 7) geri kazanımında uygulama alanı bulmuştur.

Atık plastiklerin geri dönüşümünde özellikle yüksek oranlarda kullanım alanları bulunan PET ve PVC'nin flotasyon ile ayrılmasında birçok araştırmacı çalışmalarda bulunmuştur [21-25]. PET $\left(1.33-1.38 \mathrm{~g} / \mathrm{cm}^{3}\right)$ ile PVC'nin (1.32-1.42 g/ $\left.\mathrm{cm}^{3}\right)$ yoğunluk değerleri ve hidrofobik özellikleri birbirine yakındır [26, 27]. Bu sebeple de flotasyon ile ayırmada plastikleştirici kimyasallar (reaktifler) kullanarak yüzey özelliklerinin değiştirilmesi gerekmektedir. Kılı̨̧ ve Yüce [28] yaptıkları çalışmada, aşırı bazik sodyum hidroksit çözeltisi (pH ayarlayıcı), Diethylene Glycol Dibenzoate ve Lignin Alkali (plastikleştirici) ve Metil İzobütil Karbinol (MIBC) (köpürtücü) kullanarak PET ve PVC'nin birbirinden ayrılabileceği koşulları belirlemişlerdir. Kullanılan reaktifler PET'in yüzeyinin hidrofobik özelliklerini değiştirirken PVC'ninkini yüksek oranda etkilememiştir. Böylelikle bu iki polimerin yüksek verimlerle ayrıştırılması sağlanmıştır. 


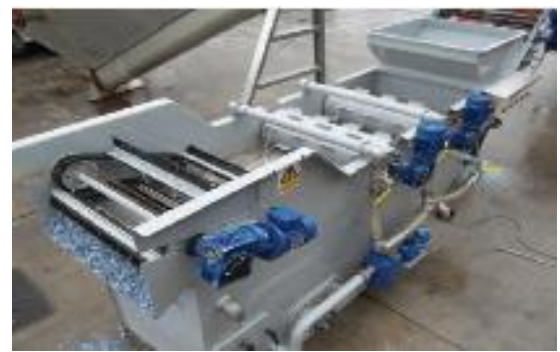

Şekil 7. Flotasyon ile plastiklerin ayrıştırılması [6]

Hurda kâğıtların tekrardan kâğıt üretimine geri dönebilmesi için üzerindeki baskı mürekkebinden temizlenmesi gerekmektedir. Flotasyon yöntemin de uygun kimyasalların kullanılmasıyla mürekkep köpüğe yapışarak yüzdürülmekte temizlenen kâğıtlar batmaktadır (Şekil 8) [29].

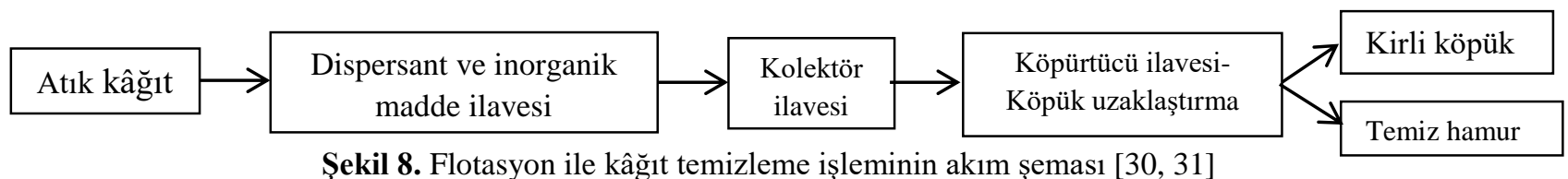

Şekil 8. Flotasyon ile kâğıt temizleme işleminin akım şeması [30, 31]

\subsection{Kimyasal Yöntemler}

Kimyasal ayırma işlemler özellikle hidrometalurjik yöntemler malzemelerin kimyasal çözünürlük farkından yararlanılarak sulu ortamda uygun bir çözücü reaktif kullanılarak seçimli olarak çözeltiye alınması (liç) ve daha sonra da çeşitli arıtma ve kazanma teknikleri kullanılarak saf bileşik eldesine dayanmaktadır. Hidrometalurjik yöntemlerin yanı sıra pirometalurjik, elektrometalurjik, biyo-metalürjik süreçler ve bunların kombinasyonları uygulanabilmektedir. Geri dönüşüm proseslerinde söz konusu yöntem ve/veya yöntemler kullanılarak en çok elektronik atıklar (e-atık) ayrılmaktadır. Günümüzde elektronik atık sınıfına; elektronik cihazlar, elektronik devreler ve bileşenler (yani yarı iletkenler (entegre devreler, transistörler, diyotlar), pasif bileşenler (rezistör, kapasitor, indüktör) ve elektro-optik bileşenler (CRT'ler, LED'ler, CCD'ler, lazerler) algılayıc1lar (transistörler, MEM cihazları) ve elektronik paketler (baskılı devreler, bağlantı cihazları) tarafindan birincil fonksiyonlarını sağlayan ürün veya aletler girmektedir [32]. Şekil 9'da bir elektronik atık ayırma sürecinin akım şeması verilmektedir. Bu süreçte, sökme işlemine tabi tutulan atık devre kartları bazı fiziksel işlemlere tabi tutulurlar. Metal ve metal olmayan fraksiyonları ayırmak için boyut küçültme işleminden sonra manyetik ayırma, EddyCurrent akımlı ayırma, yoğunluk farkına dayalı ayırma vb. teknikler uygulanır. Son olarak, hidrometalurjik, pirometalurjik, elektrometalurjik, biyo-metalürjik süreçler ve/veya bunların kombinasyonları kullanılarak bir rafinasyon prosesi gerçekleştirilir ve kıymetli metaller geri kazanılır. Yapılan araştırmalar incelendiğinde, eatıkların hidrometalurjik yöntemle geri kazanımı 1960'lara kadar dayanmaktadır ve bu proseslerde metal içeriği kuvvetli sülfürik asit, hidroklorik asit, nitrik asit, aqua regia ve alkalileri içeren liç çözeltilerinde çözülebilmektedir [33]. Son 20 yılda ise yapılan araştırmalar da bioliç yöntemlerinin e-atıklardan metallerin kazanımında etkili rol oynadığı da ortaya konmuştur [33-36].

Elektronik atıkların dışında, atık/kullanılmış pillerden yukarıda bahsi geçen süreç/süreçler uygulanarak nikel, kadmiyum, demir, kobalt, civa, çinko, çelik, mangan ve diğer metaller kazanılmaktadır [37, 38].

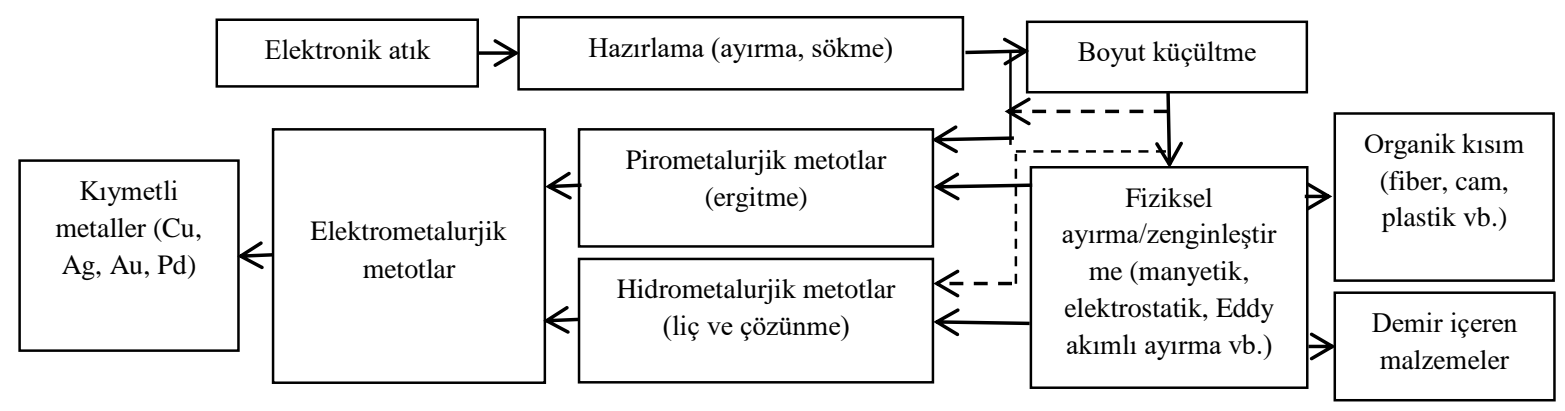

Şekil 9. Bir elektronik atık ayırma süreci akım şeması [39] 


\section{SONUÇLAR}

Yüksek yaşam standardı hayatımıza birçok imkân ve kolaylık sunarken, teknolojik ürünlerin çok çabuk tüketilip atıl duruma düşmesine yol açmıştır. Kullanılmayan ve miktarı hızla artan atıkların depolama alanı ve çevre sorunları ortaya çıkmıştır. Dolayısıyla süreç içerisinde atıkların geri dönüşümü ile yeni ve ikinci hammadde kaynaklarının oluşturulabileceği anlaşılmıştır.

Geri dönüşüm prosesleri incelendiğinde, her kademesinde (kırma, öğütme, eleme sınıflandırma, fiziksel fiziko kimyasal-kimyasal ayırma vb.) cevher hazırlama ve zenginleştirme tesislerinde kullanılan ekipmanların çoğunun kullanıldığı ve başarıyla uygulandığı göze çarpmaktadır.

$\mathrm{Bu}$ çalışma ile geri dönüşüm endüstrisinde kullanılan cevher hazırlama ekipmanları ve prosesleri (el ile ayıklama, otomatik ayırma, manyetik ayırma, elektro statik ayırma, gravite yöntemleri ile ayırma, flotasyon, liç) hakkında güncel bilgiler verilmiş ve ayrıca uygulama örnekleri sunulmuştur.

\section{KAYNAKLAR}

[1] AKCILL, A., YAZICI, E.Y., DEVECI, H., “E-Atıklar: Geleceğin Madenleri”, Recycling Teknoloji, 10, 64-73, 2009.

[2] DEMIREL, H., KARAPINAR, N., "Çevre Sorunlarının Çözümünde Madencilik Teknolojilerinin ve Bilgi Birikimlerinin Kullanımı”, 21. Yüzyıla Girerken Türkiye Madenciliği, 33-49, Sivas Türkiye, 1996.

[3] KARAPINAR, N., "Cevher Zenginleştirme Yöntemlerinin Geri Kazanım Endüstrisindeki Yeri” Ulusal Sanayi ve Çevre Sempozyumu, 286-295, Mersin, Türkiye, 2001.

[4] GÜLCAN, E., "Minerallerin Optik Ayırma İle Ayrılabilirliğinin Araştırılması”, Hacettepe Ü. Fen Bil. Ens., Yüksek Lisans Tezi, 2013.

[5] https://www.iva.se/globalassets/presentationer-fran-seminarier/ekberg--iva-20180112---framtidensbatterier-id-114812.pdf (erişim tarihi 23.12.2018)

[6] http://www.turkchem.net/plastik-geri-donusumunde-zorluklar-firsatlar.html (erişim tarihi 23.12.2018)

[7] ZHANG, S., REM, P.C., FORSBERG, E., "The Investigation of Separability of Particles Smaller than $5 \mathrm{~mm}$ by Eddy Current Separation Technology. Part I: Rotating Type Eddy Current Separators", Magnetic and Electrical Separation, 9, 233-251, 1999.

[8] HACIFAZLiOĞLU, H., "Manyetik Ayırmadaki Son Gelişmeler ve Alternatif Manyetik Ayırıcı Tiplerinin Tanıtılması“, İstanbul Yerbilimleri Dergisi, 24, 75-93, 2011.

[9] https://www.metso.com/globalassets/saleshub/documents---episerver/lims_iron_ore_brochure-en.pdf

[10] https://recyclingmachinery.net/product/eddy-current-separators/ (erişim tarihi 20.09.2018)

[11] https://www.sydensen.com/Eddy-Current-Separator-for-PET-Recycling-pd434212.html (erişim tarihi 20.09.2018)

[12] ÖNAL, G., Cevher Hazırlamada Flotasyon Dışındaki Zenginleştirme Yöntemler, İstanbul Teknik Üniversitesi Yayınları, İstanbul, Türkiye, 1985.

[13] TILMATINE, A., Hammadi, N., REMAOUN, S.S., MEDLES, K., NEMMİCH, S., DASCALESCU, L., "Processes for Sustainable Development Using High-Intensity Electric Fields", International Journal of Sustainable Engineering, 6, 177-185, 2013.

[14] SAEKI, M., "Triboelectric Separation of Three-Component Plastic Mixture", Particulate Science and Technology, 26, 494-506, 2008.

[15] ZANG, G., WANG, H., HE, Y., YANG, X., ZHEN, P., ZHANG, T., WANG, S., “Triboelectric Separation Technology for Removing Inorganics from Non-Metallic Fraction of Waste Printed Circuit Boards: Influence of Size Fraction and Process Optimization”, Waste Management, 60, 42-49, 2017.

[16] BITTNER, J.D., FLYNN, K.P., HRACH, F.J., Expanding Applications in Dry Triboelectric Separation of Minerals", $17^{\text {th }}$ International Mineral Processing Congress, 1-13, Santiago, Chile, 2014.

[17] WILLS, B.A., NAPIER-MUNN, T., "Wills' Minerals Processing Technology", (7 $7^{\text {th }}$ ed.), Elsevier Science \& Technology Books, Amsterdam, Netherlands, 2006.

[18] https://akyurekltd.com/tr/Vibro-Cop-Sasoru-14s.html (erişim tarihi 23.12.2018)

[19] http://www.molino.com.tr/tr-TR/Urunler/2 temizleme/45 kuru-tas-ayirici/ (erişim tarihi 23.12.2018)

[20] ÖZKOLO, S., “Çevre Koruma Hizmetinde Flotasyon”, Madencilik, 33, 25-29, 1994.

[21] SHEN, H., FORSSBERG, E., PUGH, R. J., "A Review of Plastics Waste Recycling and the Flotation of Plastics", Resources, Conservation and Recycling, 25, 85-109, 1998. 
[22] DRELICH, J., KIM, J. H., PAYNE, T., MILlER, J. D., KOBLER, R. W., "Purification of Polyethylene Terephthalate from Polyvinyl Chloride by Froth Flotation for the Plastics (Soft-Drink Bottle) Recycling Industry", Separation and Purification Technology, 15, 9-17, 1999.

[23] LE GUERN, C., CONIL, P., HOUOT, R., "Role of Calcium Ions in the Mechanism of Action of a Lignosulphonate Used to Modify the Wettability of Plastics for their Separation by Flotation", Minerals Engineering, 13 (1), 53-63, 2000.

[24] PASCOE, R. D., O'CONNELL, B., "Flame Treatment for the Selective Wetting and Separation of PVC and PET", Waste Management, 23, 845-850, 2003.

[25] TAKOUNGSAKDAKUN, T., PONGSTABODEE, S., "Separation of Mixed Post Consumer PETPOM-PVC Plastic Waste Using Selective Flotation”, Separation and Purification Technology, 54, 248-252, 2006.

[26] SHEN, H., PUGH, R. J., FORSSBERG, E., "Floatability, selectivity and flotation separation of plastics by using a surfactant", Colloids and Surfaces A: Physicochemical and Engineering Aspects, 196, 63-70, 2002.

[27] KILIÇ, M., YÜCE, E., "PVC ve PET Atıkların Seçimli Flotasyonu Bölüm 1: Plastikler; Çevresel Etkileri; Geri DönüGümü”, Çukurova Üniversitesi Mühendislik Mimarlık Fakültesi Dergisi, 29(2), 79-93, 2014.

[28] KILIÇ, M., YÜCE, E., "PVC ve PET Atıkların Seçimli Flotasyonu Bölüm 2: Laboratuar ve Pilot Ölçekli Kolon Testleri”, Çukurova Üniversitesi Mühendislik Mimarlık Fakültesi Dergisi, 29, 95-113, 2014.

[29] İMAMOĞLU, S., “Atık Kâğıt Hamurlarının Formamaidin Sülfinik Asit (FAS) ile Ağartılması”, İstanbul Üniversitesi Fen Bil. Ens., İstanbul, 2002.

[30] FERGUSON, L.D., "Deinking Chemistry: Part 2.”, Tappi J., 75 (8), 49-57, 1992.

[31] KARADEMIR, A., KARAHA, S., İMAMOĞLU, S., ERTAŞ, M., AYGAN, A., AYDEMIR, C., PEŞMAN, E., "Kâğıt Geri Dönüşümünde Enzim ve Ultrasonik Enerji Kullanımı", Tarih Kültür ve Sanat Araştırmaları Dergisi, 1, 280-297, 2012.

[32] KAYA, M., SÖZERI, A., "Elektronik Atık (E-Atık) Geri Dönüşümü/Kazanımı, AB Sürecinde Türkiye'de Katı Atık Yönetimi ve Çevre Sorunları Sempozyumu", 13th International Energy, Cogeneration And Environmental Technologies Conference \& Exhibition, 28-31, Mayıs, İstanbul, 2007.

[33] ABDELBASIR, S.M., HASSAN, S.S.M., KAMEL, A.H., EL-NASR, R.S., "Status of Electronic Waste Recycling Techniques: a Review", Environmental Science and Pollution Research, 25, 1655316547, 2018.

[34] BRANDL, H., BOSSHARD, R., WEGMANN, M., “Computer-munching Microbes: Metal Leaching from Electronic Scrap by Bacteria and Fungi”, Hydrometallurgy, 59, 319-326, 2001.

[35] BRIERLEY, J.A., BRIERLEY, C.L., "Present and Future Commercial Applications of". Hydrometallurgy, 59, 233-239, 2001.

[36] CHOI, M.S., CHO, K.S., KIM, D.S., KIM, D.J., Microbial Recovery of copper from printed circuit boards of waste computer by Acidithiobacillus ferrooxidans", J Environ Sci Health A., 39,2973-2982, 2004.

[37] KURŞUNOĞLU, S., “Atık/Kullanılmış Çinko-Karbon ve Alkali Pillerden Çinko ve Manganın Geri Kazanılması”, Eskişsehir Osmangazi Ü. Fen Bil. Ens., Yüksek Lisans Tezi, 2010.

[38] KAYA, M., KURŞUNOĞLU, S., "A Review of the Current Hydrometallurgical Recycling of Spent AA and AAA Size Zn-C and Alkaline Batteries", European Metallurgical Congress, Dusseldorf, Germany, 2011.

[39] TUNCUK, A., STAZİ, V., AKÇíL, A., YAZICI, E.Y., DEVECİ, H., “Aqueous Metal Recovery Techniques from E-Scrap: Hydrometallurgy in Recycling”, 25, 28-37, 2012. 